\title{
Assessment of Sweet Potato Peel as a Potential Raw Material for Bioethanol Fuel
}

\author{
Ogunsuyi Helen Olayinka \\ Department of Chemistry, Federal University of Technology, P.M.B 704, Akure Ondo State of Nigeria
}

\begin{abstract}
The feasibility of producing bioethanol from Sweet Potato (Ipomoea batatas) peels using fermentation process was examined. The gelatinized sample of sweet potato was subjected to a two stage enzyme hydrolysis using bacterial alpha-amylase (Amylitic-TS) and fungal alpha-amylase (AMG) to produce fermentable sugar solution. The hydrolyzed liquor was inoculated with Industrial baker's yeast (saccharomyces cerevisiea) and gave ethanol yield of $11.60 \%$ after 7 days of fermentation. The efficiency of the fermentation process was evidenced by the decline in the $\mathrm{pH}$ and brix level of the fermented sugar solution. The $\mathrm{pH}$ dropped from 8.50 to 4.82 and brix level fall from 16.0 to 3.0. The reduced $\mathrm{pH}$ enhanced the optimum activity of the yeast. The decrease in the $\mathrm{pH}$ enabled the population of fungal to increase significantly from $3.10 \times 10^{4} \mathrm{sfu} / \mathrm{ml}$ to $3.20 \times 10^{5} \mathrm{sfu} / \mathrm{ml}$ after day 7 . Conversion of wort to ethanol was optimum at the lowest specific gravity value of 0.9830 . This trend can be attributed to steady decline in the brix level as fermentation process progressed.
\end{abstract}

Key words: Sweet Potato (Ipomoea batatas), ethanol, enzyme, hydrolysis, Saccharification.

\section{INTRODUCTION}

One of the critical challenges facing African continent at present is the acute shortage of energy supply. In most developing countries in Africa, Nigeria in particular, domestic energy is grossly insufficient both at the rural and urban settlements, since provision of domestic fuel (Kerosene and cooking gas) has been the sole responsibility of the Federal Government. Apart from the insufficiency of these commodities to meet the increasing demands, the cost of sale is relatively high. Thus, many rural settlers and low income earners cannot afford to use them. For instance, in Nigeria, a full bag of charcoal that can sustain the domestic cooking of an average family of five persons for a period one month is sold for an equivalent of 7USD, compared to a domestic cooking fuel like kerosene that requires a minimum of 30 USD per month to sustain an average family of five. Hence, the high cost of liquid fuel like kerosene has influenced the decision of many citizens, especially the low income earners and rural people to embrace the option of solid fuels such as firewood, charcoal and saw dust stove as alternatives. This high rate of solid fuel consumption has brought about persistent cutting of trees for firewood and charcoal making, Hence, devastation of forest reserves through deforestation has been identified as one root causes of climate change in African countries, especially in Nigeria (Nwike, 2011). The health of the rural dwellers who are the major users of this form of energy is always at great risk because of the smoke emanating from the cooking's. Statistic shows that urban population in Nigeria was $49.1 \%$ of the 170 million residents as at 2011 , while the remaining quota is due to rural population (Nigeria Demographics Profile, 2014). Reports have it that no fewer than 98,000 Nigerian women die annually from smokes inhaled during cooking with firewood (Vanguard News, 2013). Besides, environmental pollution resulting from fossil energy is as well on the increase daily. Therefore, the need to quest for alternative energy that is clean, cheap, renewable and environmentally friendly becomes very critical.

Renewable energy is currently being developed as suitable alternatives to conventional fossil energy in many countries of the world. Among these alternatives are biofuels that comprise various forms of fuels obtainable from biomass. Bio-fuels are considered reliable substitutes in view of their intrinsic qualities such as renewability, sustainability, biodegradability, non- toxicity, and nonemissions of greenhouse gases. Bio-ethanol has been reported as a clean form of liquid fuel that does not pose any health threats to the consumer (Hall and Smittle, 1993). Presently, research efforts are being focused on generating bioethanol from biomass resources that will not compete with food chain Nwaoguikpe, 2011; Saucedo, 1991 Parameswaran et al, 2011). Bioethanol fuel is preferred to its fossil-sourced counterparts because of its zero-carbon emission or $\mathrm{CO}_{2}$ neutrality (European Commission Press Release).

Basically, acid, alkaline and enzymatic hydrolysis are commonly used for hydrolyzing biomass .Hydrolysis breaks down cellulose and hemicelluloses of biomass into sugar solution that can be fermented into ethanol through the action of yeasts (Kuboye and Akinrele, 1971; Suraswati, 1988; Jaleel et al., 1988).

Due to the feasibility of generating clean and reliable energy from biomass through fermentation process, the present research effort will focus attention on the production of bio-ethanol from sweet potato peels Sweet potato (Ipomoea batatas) belongs to the family of Convolvulaceaehas and has been considered a promising substrate for alcohol production due to its higher starch yield than grains (Duvernay et al. 2013; Lee et al. 2012; Srichuwong et al.2009; Ziska et al. 2009). Sweet potato is traditionally consumed in boiled form with varying accompaniments including cowpea, rice, millet and 
benniseed. In semi-arid zone, sweet potato flour is $\mathbf{2 . 3}$ Production media and inoculation

popularly used for sweetening local foods while in the $250 \mathrm{~mL}$ of the hydrolysed liquor was mixed with $400 \mathrm{~mL}$ urban markets of the humid south, sweet potato fries are of deionized water. $3 \mathrm{~g}$ of glucose, $1 \mathrm{~g}$ of urea and $1 \mathrm{~g}$ of produced and marketed. The sweetness of the clones ammonium hydrogen phosphate were added to the mixture makes sweet potato undesirable as staple food in Nigeria. and autoclaved for $30 \mathrm{~min}$ at a temperature of $121^{\circ} \mathrm{C}$ and a Therefore, return on investments in sweet potato pressure of $760 \mathrm{mmHg}$. The sterile liquor was cooled to cultivation is marginal. Cultivation of root and tuber crops $30^{\circ} \mathrm{C}$ and the $\mathrm{pH}$ was adjusted to 4.5 . $100 \mathrm{~mL}$ of the sterile in Nigeria as in most African countries is threatened by the low prices of the crops and their products. With the rising cost of labour and transportation, rural farmers can hardly sustain their farming systems considering the meagre returns from their harvest. It is therefore advantageous to diversify the use of the root-crop beyond those of the traditional food industry (Tewe et al, 2003). Therefore, diversification into other uses, especially its peels as feedstock for bioethanol will increase demand, ensure attractive prices and consequently encourage farmers, particularly, smallholder farmers to sustain and expand their root-crop farming. Ultimately, it will address the domestic energy needs of the populace.

\section{MATERIALS AND METHODS}

\subsection{Gelatinization of sweet potato peels}

Corns of sweet potato cultivars were washed and peeled. The peel was mashed and $100 \mathrm{~g}$ of the mash were weighed into a trough containing $150 \mathrm{~mL}$ of water and the contents were stirred thoroughly to homogenize the mixture. The mixture was poured into a pressure pot and cooked for 30 min at a pressure of $10 \mathrm{psi}$ and temperature of $110^{\circ} \mathrm{C}$ (A.O.A.C, 1990).

\subsection{Saccharification of the gelatinized sample}

Prior to hydrolysis, the assay of the Alpha amylase was done using analytical procedure as described by Demoraes et al, (1999) and that of Amyloglucosidase was done using analytical procedure as described by Cereia et al, (2000)

The method of saccharification adopted was as described by Braide and Nwaoguikpe, 2011 The process involved a 2-stage enzyme hydrolysis. The first stage involved the use of bacterial alpha-amylase (a liquefying agent) which broke down the starch, content of the gelatinized sample while the hydrolysis was accomplished at the second stage with fungal alpha-amylase (a saccharifying agent). 800 $\mathrm{mL}$ of water was added to make the slurry of the gelatinized sample. In the first stage, $1 \mathrm{ml}$ of $0.1 \mathrm{~N}$ solution of bacterial alpha amylase (Amylitic-TS) was added to the slurry and $\mathrm{pH}$ and temperature were adjusted to 6.0 and $100^{\circ} \mathrm{C}$ respectively. A partially liquefaction of the mixture was achieved on continuous agitation for $45 \mathrm{~min}$. In the second stage, the solution was cooled to $64^{\circ} \mathrm{C}$ and the $\mathrm{pH}$ was adjusted to 5.4 to favors the activities of fungal alpha amylase. $2 \mathrm{ml}$ of $0.1 \mathrm{~N}$ solution of fungal alpha-amylase (AMG) was added to the slurry. The solution was agitated in water bath for $45 \mathrm{~min}$ to obtain complete liquefaction of the slurry (Miller and Litsky, 1976). In order to stop the action of the enzyme and to sterilize the broth, the slurry was further heated for $10 \mathrm{~min}$ at $100^{\circ} \mathrm{C}$. The saccharified liquor was cooled to $28^{\circ} \mathrm{C}$ and $\mathrm{pH}$ was adjusted to 4.5 . The brix level and specific gravity was determined by standard methods (A.O.A.C, 1990). (saccharomyces cerevisiea) in a sterile $250 \mathrm{~mL}$ uniscope beaker. $200 \mathrm{ml}$ of the yeast was allowed to grow for $1 \mathrm{~h}$ before pitching into the main inoculum broth, and aerated by shaking at a speed of $1000 \mathrm{rpm}$ at room temperature for 48h (A.O.A.C, 1990).

\subsection{Alcoholic fermentation of broth sample}

$400 \mathrm{~mL}$ of the inoculum was pitched into $2 \mathrm{~L}$ of hydrolysed liquor in a flask and aerated before closing with cotton wool. Fermentation was allowed to take place for 7 days at $30^{\circ} \mathrm{C}$. The brix level, $\mathrm{pH}$, specific gravity and percentage alcohol by volume produced were determined daily and recorded (A.O.A.C, 1990).

\subsection{Chemical analysis of the sample during alcoholic} fermentation

Hydrogen ion concentration $(\mathrm{pH})$ of the sample was determined with a uniscope $\mathrm{pH}$ meter. The method described in A.O.A.C (1990) was adopted. Specific gravity was determined according to the method 945.06 (A.O.A.C, 1990). Specific gravity was calculated by standard method. Brix level of the sample was determined by hand refractometer method (A.O.A.C, 1990). Simple distillation method described in A.O.A.C (1990) was used in the determination of percentage alcohol in the sample. Microscopic and biochemical characteristics was determined by methods described in), Harrigan and McCance (1976) and Harrigan and McCance (1990).

\section{RESULTS AND DISCUSSION}

\subsection{Results}

Table1. Mean $\mathrm{pH}$ values of fermenting broth for 7 days

\begin{tabular}{|c|c|}
\hline $\begin{array}{l}\text { Period of } \\
\text { fermentation (days) }\end{array}$ & $\begin{array}{l}\text { pH values } \\
\text { (Mean } \mathbf{\pm S D} \text { ) }\end{array}$ \\
\hline $\mathbf{1}$ & $8.50 \pm 0.2$ \\
\hline $\mathbf{2}$ & $6.22 \pm 0.2$ \\
\hline $\mathbf{3}$ & $5.18 \pm 0.1$ \\
\hline $\mathbf{4}$ & $5.10 \pm 0.2$ \\
\hline $\mathbf{5}$ & $5.06 \pm 0.2$ \\
\hline $\mathbf{6}$ & $5.00 \pm 0.4$ \\
\hline $\mathbf{7}$ & $4.82 \pm 0.1$ \\
\hline
\end{tabular}

Table2: Total soluble solids content of the fermenting broth

\begin{tabular}{|l|l|}
\hline $\begin{array}{l}\text { Period of } \\
\text { fermentation (days) }\end{array}$ & $\begin{array}{l}\text { Brix Level (TSS) } \\
\text { (Mean } \pm \text { S.D) }\end{array}$ \\
\hline $\mathbf{1}$ & $16.0 \pm 0.2$ \\
\hline $\mathbf{2}$ & $8.0 \pm 0.4$ \\
\hline $\mathbf{3}$ & $7.0 \pm 0.3$ \\
\hline $\mathbf{4}$ & $5.2 \pm 0.2$ \\
\hline $\mathbf{5}$ & $3.5 \pm 0.1$ \\
\hline $\mathbf{6}$ & $3.1 \pm 0.2$ \\
\hline $\mathbf{7}$ & $3.0 \pm 0.1$ \\
\hline
\end{tabular}


Table3. Specific gravity and percentage alcohol produced $($ Mean \pm SD)

\begin{tabular}{|l|l|l|}
\hline $\begin{array}{l}\text { Period of } \\
\text { fermentation } \\
\text { (days)_ }\end{array}$ & $\begin{array}{l}\text { Specific } \\
\text { gravity }\end{array}$ & $\begin{array}{l}\text { \% alcohol } \\
\text { produced }\end{array}$ \\
\hline 1 & $11.0000 \pm 0.1$ & 0.00 \\
\hline 2 & $0.9991 \pm 0.1$ & $0.40 \pm 0.1$ \\
\hline 3 & $0.9963 \pm 0.3$ & $1.50 \pm 0.1$ \\
\hline 4 & $0.9955 \pm 0.1$ & $2.00 \pm 0.2$ \\
\hline 5 & $0.9901 \pm 0.2$ & $5.00 \pm 0.1$ \\
\hline 6 & $0.9850 \pm 0.1$ & $8.10 \pm 0.2$ \\
\hline 7 & $0.9830 \pm 0.3$ & $11.60 \pm 0.3$ \\
\hline
\end{tabular}

Table 4: Bacterial and fungal count of the sample at different fermentation period

\begin{tabular}{|l|l|l|}
\hline $\begin{array}{l}\text { Fermentation } \\
\text { periods (Day) }\end{array}$ & $\begin{array}{l}\text { Bacterial } \\
\text { counts }(\mathbf{c f u} / \mathbf{m l})\end{array}$ & $\begin{array}{l}\text { Fungal count } \\
\text { in }(\mathbf{s f u} / \mathbf{m l})\end{array}$ \\
\hline 1 & $1.88 \times 10^{7}$ & $3.10 \times 10^{4}$ \\
\hline 2 & $8.20 \times 10^{6}$ & $7.30 \times 10^{4}$ \\
\hline 3 & $4.10 \times 10^{6}$ & $1.30 \times 10^{5}$ \\
\hline 4 & $1.20 \times 10^{6}$ & $1.90 \times 10^{5}$ \\
\hline 5 & $0.80 \times 10^{6}$ & $2.20 \times 10^{5}$ \\
\hline 6 & $0.50 \times 10^{6}$ & $2.90 \times 10^{5}$ \\
\hline 7 & $0.20 \times 10^{6}$ & $3.20 \times 10^{5}$ \\
\hline
\end{tabular}

Table 5: Comparative analysis of commercial ethanol and bioethanol produced from (Ipomoea batatas) peel.

\begin{tabular}{|l|l|l|}
\hline $\begin{array}{l}\text { Ethanol } \\
\text { properties }\end{array}$ & $\begin{array}{l}\text { Bioethanol from } \\
\text { Ipomoea batatas }\end{array}$ & $\begin{array}{l}\text { Commercial } \\
\text { Ethanol }\end{array}$ \\
\hline Appearance & Colourless & Colourless \\
\hline $\begin{array}{l}\text { Relative } \\
\text { density }\end{array}$ & $0.75 \mathrm{~g} / \mathrm{cm}^{3}$ & $0.789 \mathrm{~g} / \mathrm{cm}^{3}$ \\
\hline Melting point & $-113^{\circ} \mathrm{C}$ & $-114^{0} \mathrm{C}$ \\
\hline Boiling point & $78.5^{\circ} \mathrm{C}$ & $78.37^{\circ} \mathrm{C}$ \\
\hline Viscosity & 0.0122 & $\begin{array}{l}0.0012 \text { pa s at } \\
20^{\circ} \mathrm{C}\end{array}$ \\
\hline $\begin{array}{l}\text { Burning } \\
\text { characteristics }\end{array}$ & $\begin{array}{l}\text { Burns with blue } \\
\text { flame }\end{array}$ & $\begin{array}{l}\text { Burns with } \\
\text { blue flame }\end{array}$ \\
\hline $\begin{array}{l}\text { Refractive } \\
\text { index }\end{array}$ & 1.36 & 1.36 \\
\hline Flash point & $12^{\circ} \mathrm{C}$ & $13-14^{\circ} \mathrm{C}$ \\
\hline
\end{tabular}

\subsection{DISCUSSION}

Table 1 shows the changes in the $\mathrm{pH}$ as the fermentation process progresses, up to day 7 . The initial $\mathrm{pH}$, at day 1 was 8.50, showing that the Ipomoea batatas peel is alkaline in nature. After day 2 , the $\mathrm{pH}$ drastically reduced to 6.22 and finally maintained a $\mathrm{pH}$ of 3.0 at the end of day 7 . The changes in the $\mathrm{pH}$ may be attributed to the acid released by the acid producing microorganisms present in the fermentation process. . The gradual lowering of the $\mathrm{pH}$ of the medium created an enabling environment for the conversion of the sugars present in the medium by the yeast, thereby optimizing the activity of the yeast.

Table 2 shows that the total soluble solids (brix level) of the broth decreased with an increase in the period of fermentation until a constant value was obtained. That is, the brix level dropped as the yeast utilized the sugars and reduced its quantity in the medium. The specific gravity of the broth decreased with an increase in alcoholic content of the fermenting broth (Table 3 ). The Table reveals that as the period of fermentation increased the specific gravity of the broth decreased while the level of alcohol produced increased. Table 3 also shows the correlation between the specific gravity, percentage alcohol produced and the period of fermentation. The result reveals that the yeast cells were inactive at the initial stage of the fermentation, presumed to be the lag phase. As from the fifth day, depletion of sugar was very rapid and the rate of carbon dioxide evolution was vigorous with resultant increase in the percentage of alcohol produced.This period (lag phase) is characterized by rapid cell multiplication indicated by rapid fermentation. This observation is quite consistent with the findings of Braide and Nwaoguikpe,(2011 for cocoyam bioethanol.)

Table 4 shows the microbial population of the fermentation process. The bacterial population at day 1 was the highest at $1.88 \times 10^{7} \mathrm{cfu} / \mathrm{ml}$ and bacterial populations reduced to $8.20 \times 10^{6} \mathrm{cfu} / \mathrm{ml}$ after day 2 . The lowest bacterial population of $1.20 \times 10^{6} \mathrm{cfu} / \mathrm{ml}$ was recorded at day 7 . The progressive reduction in the bacterial population can be attributed to several factors among which are lowered $\mathrm{pH}$, production of certain chemicals by some strains of microorganisms, such chemicals that have inhibitory effect on other organisms.

Unlike the bacterial population, the fungal population increased significantly, from $3.10 \times 10^{4} \mathrm{sfu} / \mathrm{ml}$ at day 1 and to $3.20 \times 10^{5} \mathrm{sfu} / \mathrm{ml}$, at day 7 . The steady increase noted in the Fungi population can be explained on the survival ability of fungi under acidic conditions and other various unfavorable conditions.

Table 5 depicts the comparison between the properties of Ipomoea batatas bioethanol and those of the conventional ethanol. The flash point of the conventional ethanol ranges between $13^{\circ} \mathrm{C}$ and $14^{\circ} \mathrm{C}$ and slightly higher than $12^{\circ} \mathrm{C}$ noted for Ipomoea. The distilled bioethanol appeared colourless and has a boiling point of $78.5^{\circ} \mathrm{C}$, which is very close to that of the conventional ethanol. Generally, the correlation between the properties of the two alcohols shows that bioethanol derived from plant sources can serve similar purpose as their conventional counterparts. All the above results show the feasibility of producing bioethanol from sweet potato peels. While the cultivar tube is used as food and food supplement, the peels can be hydrolyzed and fermented to bioethanol for domestic consumption as fuels. This new avenue of using sweet potato peels will encourage wholesome utilization of the plant crop, boost interest of farmers in cultivating the crop and consequently enhances rural economy.

\section{REFERENCES}

1. Hall and Smittle. 1993. Industrial-type sweet potatoes: A renewable energy resource for Georgia. UGA Res. Rpt. 429.

2. Nwike, E.C. (2011): The Role of Rural Women in Despoilation of the Environment Journal of Arts and Social Sciences. Vol. 4, (1): 290-

W. Braide* and R. N. Nwaoguikpe Production of ethanol from cocoyam (Colocasia esculenta International Journal of Plant Physiology and Biochemistry Vol. 3(3), pp. 64-66, March 2011

4. Saucedo G, Lonsane BK, Navarro JM, Roussos S, Raimbault M (1992). Potentials of Cassava in Ethanol Production. Appl. Biochem.Biotech., 36: 47-61. 
5. Parameswaran Binod, K.U. Janu, Raveendran Sindhu, Ashok Pandey (2011), Hydrolysis of Lignocellulosic Biomass for Bioethanol Production. In Ashok Pandey,Christian Larroche, Steven C Ricke, Claude-Gilles Dussap, Edgard Gnansounou,editors: Biofuels, Burlington: Academic Press, , pp. 229-250.

6. Kuboye AO, Akinrele IA (1971). Derivation of Table Vinegar from Fermented Palmwine. FIIRO Res. Rep. Technology, No 42.,Nigeria

7. Saraswati R (1988). Paper delivered at a workshop on upgrading of Cassava/ Cassava Waste by appropriate Biotechnologies, pp 41-49.

8. Jaleel SA, Srikanta S, Ghildyal NP, Lonsane BK (1988). Starch Hydrolysis. Appl. Biochem. Biotech., 40: 55-58. Harrigan WF, McCance ME (1976). Laboratory Methods in Food and Dairy Microbiology.2nd edition, Academic Press Inc., London, p. 96.

9. Duvernay WH, Chinn MS, Yencho GC (2013) Hydrolysis and fermentation of sweet potatoes for production of fermentable sugars and ethanol. Ind Crop Prod 42:527-537

10. Srichuwong S, Sunarti TC, Mishima T, Isono N, Hisamatsu M (2005) Starches from different botanical sources I: Contribution of amyopectin fine structure to thermal properties and enzyme digestibility. CarbohydrPolym 60:529-538

11. Ziska LH, Runion GB, Tomecek M, Prior SA, Torbet HA, Sicher R (2009) an evaluation of cassava, sweet potato and field corn as potential carbohydrate sources for bioethanol production in Alabama and Maryland. Biomass Bioenergy 33(11):1503-1508

12. Lee W-S, Chen I-C, Chang C-H, Yang S-S (2012) Bioethanol production from sweet potato by co-immobilization of saccharolytic molds and Saccharomyces cerevisiae. Renew Energy 39:216-222

13. Tewe, O.O, Ojeniyi F.E and Abu O.A (2003) Sweetpotato Production, Utilization, and Marketing in Nigeria. Social Sciences Department, International Potato Center (CIP)

14. CereiaMarina,HectorF.Terenzi Joao A George,LewisJ.Green,Josec Rosa and Maria Lourdes Polizeli (2000) Glucoamylase activities from the thermophilic fungus.Journal of Basic microbiology,40(200)2, pp 83-92

15. Association of Official Analytical Chemists (A.O.A.C) (1990). Official Methods of Analysis. 5th edition, USA, pp. 899-911

16. Harrigan WF, McCance ME (1976). Laboratory Methods in Food and Dairy Microbiology.2nd edition, Academic Press Inc., London, p. 96.

17. Harrigan WF, McCance ME (1990). Laboratory Methods in Food and Dairy Microbiology. 5th edition, Academic Press Inc., London, pp. 46- 54 . 